\title{
How to Measure Business Value of Information Systems? Practical Implications of a Literature Review
}

\author{
Marta Aranyossy \\ Assistant professor, Department of Enterprise Finances, Corvinus University of Budapest, Budapest, Hungary
}

\begin{abstract}
In 2014 IT spending reaches 3,75 billion USD according to Gartner's forecast, while this years Standish Group report shows that $31 \%$ of projects will be cancelled before completion. These facts and the tightening of corporate budgets highlight the importance of IT valuation ex ante and ex post as well. This paper presents an overview of normative research on IT business valuation, while trying to stress practical conclusions supporting future management practice. Research suggests that the concurrent use of the discounted cash flow and real option methodologies can effectively support decisions as they can mutually offset each other's weaknesses, i.e. DCF's inflexibility and lack of strategic focus and ROA's complexity and lack of communicability. Also we conclude that the principal function of ex ante IT valuation lies not so much in determining an exact value as in identifying the key factors of value creation, thus support supporting management during implementation and use.
\end{abstract}

Keywords: IT value assessment, IT business value, return on investment, discounted cash-flow valuation, real option valuation, intangible valuation

\section{INTRODUCTION}

Gartner puts worldwide IT (information technology) spending at over USD 3700 billion in 2014, signaling a $2.1 \%$ growth on the previous year despite corporate budget cuts [28]. Knowing that success rate of IT projects tend to be rather low, this certainly arouse professionals' curiosity as to whether there is any value creation behind the spending figures.

Information technology (or information system) business value is captured in different studies by various effects on corporate performance, like [20]:

- the ability of IS to create a competitive advantage [34]);

- the productivity of IS at the organizational level [39];

- added value as the difference between revenues and expenses [52];

- the economic contribution of IS to management's profit-maximizing efforts [6].

All of the above approaches assign some kind of financial - revenue or efficiency - indicator to the IT investments. Based on that, Cronk and Fitzgerald [20, p. 44] define IT business value as: "the sustainable value added to the business by IS, either collectively or by individual systems, considered from an organizational perspective, relative to the resource expenditure required". This definition thus takes over the factor of sustainability characteristic from the literature on sustainable competitive advantage. The notion of competitive advantage is usually also defined from the aspect of financial value; i.e. competitive advantage is what enables a company to realize a ROI higher than the industry . average [16]. Based on these considerations we will use the following definitions (in Table 1) throughout this paper.
TABLE 1 .

BASIC CONCEPTS OF IT BUSINESS VALUE RESEARCH

\begin{tabular}{|c|c|}
\hline Concept & Definition \\
\hline $\begin{array}{l}\text { Information } \\
\text { Technology } \\
\text { (IT) }\end{array}$ & $\begin{array}{l}\text {,as denoting the technologies used for } \\
\text { processing, storing, } \\
\text { and transporting information in digital } \\
\text { form." }[14, \text { p. } 49 .]\end{array}$ \\
\hline $\begin{array}{l}\text { Inform } \\
\text { Syster }\end{array}$ & $\begin{array}{l}\text { "include any combination of information } \\
\text { technology and people's activities using that } \\
\text { technology to support operations, } \\
\text { management, and decision-making" [26, p. } \\
67 .]\end{array}$ \\
\hline $\begin{array}{l}\text { IT Business } \\
\text { Value }\end{array}$ & $\begin{array}{l}\text { „the organizational performance impacts of } \\
\text { information technology at both the } \\
\text { intermediate process level and the } \\
\text { organizationwide level, and comprising both } \\
\text { efficiency impacts } \\
\text { and competitive impacts" [43, p. } 287 .]\end{array}$ \\
\hline
\end{tabular}

\section{Measuring IS Business VAlue}

Does information technology create value for businesses? In respect of this question researchers have several times been confronted with the question of how value creation could/should be measured and demonstrated. With regard to this issue a normative and practical research perspective has been developed with a focus on the methods of financial valuation of IT investments.

Normative literature offers several methodologies for selecting IT investments (projects) for implementation, like [10, p. 4]:

selection on the basis of the general needs of the organization;

selection by way of categorizing projects;

selection based on net present value calculation or other financial analysis;

- selection against a set of weighted criteria. 
Here we plan to focus on the financial approaches in • details. However, there is no denying that in corporate practice placing the primary emphasis on value creation criteria is not necessarily a dominant approach, partly because of the principal-agent problems and partly because of power/political considerations.

\section{A. From transaction Costs to Total Cost of Ownership}

The transaction cost theory and the principal-agent theory are often referred in relation to IT investments and IT operation. IT can help reducing the costs of both internal (agency costs) and external coordination (transaction) costs [4].The agency theory [1] states that the solution to the principal-agent problem is shareholder control, which can be embodied in different contracts and monitoring systems. The main linkage between the agency theory and IT valuation is that some of the agent costs can be effectively reduced by the use of appropriate information systems. An agency costs advantage - which is not considered by the conventional microeconomic view - can be "cheaper" monitoring or a more time-saving documentation system. Moreover, IT can also be a useful tool to reduce the information asymmetry and allow shareholders insight into corporate processes thereby supplying them with up-to-date and real information aggregated at the appropriate level. IT, therefore, can reduce so-called "decision-informing costs" in addition to agency costs [31].According to the transaction cost theory interactions between market players have so-called transaction costs by which the parties fend off each other's possible opportunistic behaviour (see [61]). The usage of IT can mitigate information asymmetry; enable closer, more flexible, better monitorable and verifiable - and so less risky - cooperation between vendors and buyers; thus reducing transaction costs arising from search and coordination [33], [41], [60].

The two theories presented here shed light on those implicit benefits of IT investments which would have been overlooked by an evaluator thinking only in terms of traditional cost-benefit categories. Following this line of thought, the key to IT valuation is to explore all the possible value effects, the entire spectrum of IT investment costs and benefits. This is also the main idea at least on the cost side - behind the TCO (Total Cost of Ownership) methodology, a technique widely used in the field of IT valuation [50]. The TCO method seeks to map and quantify the whole spectrum of costs throughout the entire life of a product or service and thus ensures a better comparability of procurement options (see [27]). This method has really been made known and widespread in the field of IT investments by the Gartner Group ([13]). For example Smith - Schuff - St. Louis [51, p. 103] categorize the full range of costs related to IT procurement and investments as follows:

- $\quad$ Procurement costs (hardware, software);

- Operating costs (support, upgrades, performance evaluation, auditing, training, downtimes, virus damage, power consumption, work time loss due to private use, etc.)
Control costs (centralization and standardization in the field of implementation and maintenance).

There is a wide variety of practical methodologies designed for corporate use, similarly to the TCO methodology, of which a detailed picture is provided by Szatmári ([53, p. 25], for other multidimensional evaluation framework see also [42]):

- TCO - the Gartner Group's methodology;

TEI (Total Economic Impact) - the methodology used by a subsidiary of Forrester Research;

REJ (Rapid Economic Justification) - Microsoft's methodology;

TVO (Total Value of Opportunity) - the Gartner Group's methodology;

Real option approach (see Section 4.2.4 below).

These techniques and the transaction/agency or TCO logic presented in this chapter all serve as tools for decisionmakers to discover all possible expenditures and financial benefits linked to IT investments.

\section{B. The Valuation of Intangible Effects}

The forecasting of information technology effects and cash flows are made difficult by two basic problems: a temporal gap and a logical gap between IT investments and corporate profitability. The delayed effect is caused by the complexity and complicated dynamics of the impacts of technology and the inherently protracted nature of its introduction.

The second problem of cause and effect means that only a part of the effects of IT investments concerns categories traditionally handled by financial accounting systems (e.g. sales revenue growth, labor saving etc.), while some other effects are more like alternative costs (e.g. the cost of time out of work during system training) or are conditional (e.g. consequences of system downtime - see Figure 1). Moreover, the complete financial valuation of IT investments would require the quantification of effects like improved product quality or service standards, increased production flexibility, or even strategic considerations such as faster competitive response or laying the foundations for further innovations. These already belong to the range of so-called intangible benefits.

"A tangible benefit is one which directly affects the firm's profitability" ([48] in: [44] p. 303), while "the difference between a tangible and an intangible lies in the difficulty of estimating monetary value" (Emery in: [6], p. 11). In other words, intangible benefits do have financial value but their estimation is difficult, only possible by exploring a long chain of causes and effects.

In respect of the potential benefits of information systems, Hares and Royle [32] distinguish four major intangible categories:: intangible effects linked to internal development, customer service, forecasting and adaptation. As we progress along these categories, measuring the impacts becomes even more difficult. The strategy applied in practice is to value these hard-toquantify factors as zero, even though it can significantly distort valuation [35]. 


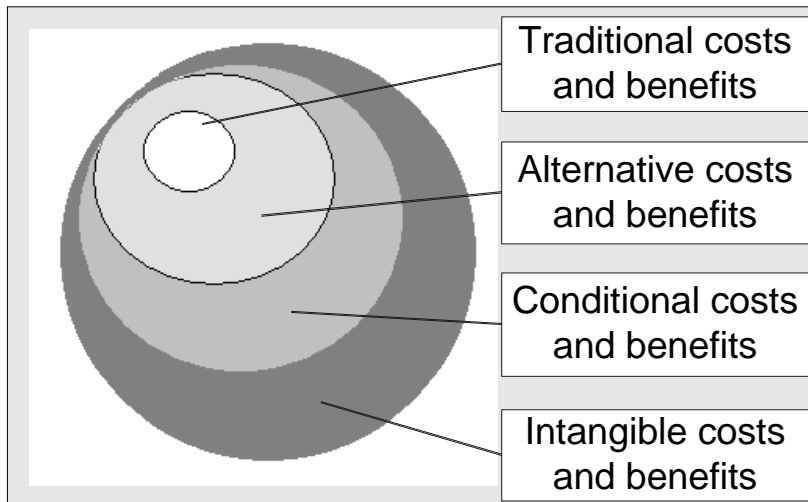

Fig. 1 Cash Flow Types of IT Investments (based on [45])

Therefore, one of the greatest challenges in valuing information technology investments lies in finding some way to determine the value of intangible benefits in monetary terms. Murphy and Simon ([44], p. 313-314) suggests the following approach to exploring the effects of IT investments:

1. Recognizing the existence of intangible benefits;

2. Making intangible benefits measurable and determining the measurement method, which can be done by rephrasing the phenomenon and assessing possible consequences;

3. "Physically" forecasting benefits; the authors present three different approaches to its implementation, respectively based on market transactions, alternative costs and direct revenues.

The second step - making intangible effects measurable often makes life difficult for the assessor while literature also offers little practical guidance. As an example, a methodology described by Anandarajan and Wen [3] can be mentioned since their goal was to ensure simple applicability in practice. The method applied by them supports the measurement of intangible benefits by expert evaluation and probability theory. They asked corporate managers to rank different intangible benefits on a numerical scale and used the frequency of responses as a probability estimate. Based on the judgment of managers they determined the probability of each scenario and the extent of extra benefit for each scenario and then calculated the expected value of the benefit as a product of the two. Naturally enough, a great disadvantage of this method is excessive subjectivity, as it only uses managers' judgment as a basis. In addition, preparing the valuation becomes a highly resource-intensive exercise and companies rarely undertake this extra investment. Experience has shown that in reality valuation mostly takes place along the following corporate process $[15, \mathrm{p}$. 152]:

1. Identifying the problem;

2. "Mini-valuation" of current business processes;

3. "Mini-valuation" of proposed business processes (enabled by the new IT investment);

4. Valuation of benefits based on the comparison of current and proposed processes.

In relation to the third step of valuation, there are a number of approaches and methods available to estimate and forecast the financial value of intangible benefits; for comparison, these can be categorized as follows (based on [21]; [22]; [47]; and [57]):

- Market-value-based approach: determination of the actual market value or estimation of the fair market value based on market transactions related to similar goods. A typical case is:

- relative valuation or valuation by multiples (i.e. the use of relative indicators of other companies, the given company being the baseline)

- Revenue-based approach: the value of future revenues to be generated from the given asset, usually determined with discounted cash flow (DCF) valuation methods.

- Cost-based approach: the cost of developing or acquiring the given asset or good. A special case is:

- determination of alternative costs (i.e. the cost of achieving the same goal if the company selected another method).

The methodological issues of quantifying intangible factors are important not only in supporting decisions but also in determining the accounting value of technology. The first time the problem became the centre of accounting experts' and researchers' attention may have been around the turn of the millennium when the market value of companies listed on the stock exchange increased to many times their book value partly as a result of their use of innovative technologies and ideas [38]. According to an American study, by 2006 the IT-based intangible asset value of an average company would reach one third of total tangible assets and depreciate at no more than 6.5 to $8 \%$ per annum [55, p. 12].

From an accounting perspective not only the definition of the intangibles but also the method of valuation is stricter and more conservative, and the historical cost as opposed to the market value is regarded as the basis. [58] That said, accounting research teams can extensively draw on business valuation approaches and a kind of convergence can be observed between the two perspectives. In their study on the new economy, the FASB (Financial Accounting Standards Board) research team drew the following and still relevant conclusions (based on [57] p. $\mathrm{X}-\mathrm{XI}$ ):

- There is no exact conceptual basis for making a distinction between purchased and internally generated intangible assets, and nor is such distinction in regulation justified.

The fact of control is an important criterion of assets. This can be strongly questionable in the case of some intangible goods (e.g. customer satisfaction), therefore they cannot be treated as assets in accounting terms.

- While on the one hand we can say that valuation based on value-generating capacity often lacks any real foundations and market reference points, costbased valuation at the same time does not provide a realistic picture about the actual value of the asset.

The most important obstacle to handling intangible assets in accounting terms lies in the fact that companies do not for the time being treat intangibles as assets; how could they then value something correctly if it falls out of their range of vision? 
Having a closer look at the arguments above we can see that these factors are obstacles not only to valuation in accounting terms but also to business/financial valuation, not to mention IT management. E.g. according to Bőgel [11] problems related to IT valuation can basically be traced to three sources: (1) the innovativeness of and continuous changes in IT; (2) interactions between projects; and (3) the time gap between investments and their effects. One of the research directions of the IT paradox was partly related to uncovering the time and correlation gaps, while the recognition and control of (intangible) IT assets is also an issue explored by the resource-based view, one of the theories prominent in IT business value research.

\section{Discounted Cash Flows in IT Valuation}

Once we have identified and quantified an ever increasing range of related cash flows (expenditures and revenues), then all we have left to do is find a valuation framework that incorporates some key principles of finance: the time value of money and the alternative cost proportionate to risk.

First, it is worth summarizing some of the cornerstones of IT valuation based on discounted cash flows (DCF - see Figure 2):

1. Estimation of cash flows: The methodological and reliability problems of exploring and estimating future cash flows were mentioned in the last two chapters, with special regard to the issue of quantifying intangible effects.

2. Uncertainty and risk: The possible decision alternatives and their probabilities have to be mapped, while the alternative cost of capital (changing over time) also has to be incorporated to the model.

3. The time value of money: Discounting assures the comparability of cash flows appearing at different points in time.

4. Evaluation: we might use more refined ex post analysis techniques to evaluate the DCF results.

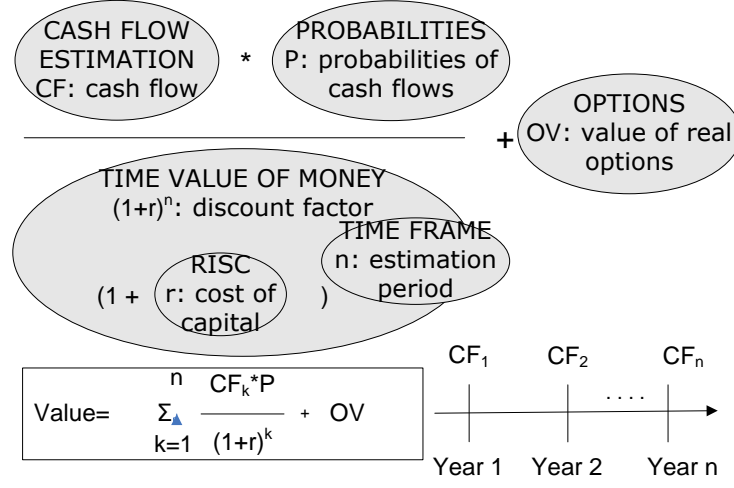

Fig. 2 IT Valuation - General Model

In respect of each cornerstone, literature highlights the following critical remarks with regard to the use of the DCF method in IT valuation (based on [17]; [3]; [37]; [49]):

- With an IT investment, even the definition and forecasting of its expected lifetime is difficult due for example to the unpredictable process of continuous upgrade services offsetting rapid technological development. Also, the uncertain timeframe makes the estimation of cash flows uncertain.

Analysis often overlooks hard-to-measure and hardto-quantify yields and expenses, whereas their value is not necessarily zero. Intangible factors like improving performance or competitive advantage and new business opportunities may make up a significant proportion of the business value of IT projects. Beyond that, the traditional DCF theoretically does not take into account management's future decisionmaking flexibility or the impact of future investment opportunities and decisions.

- In practice, the basis of comparison is usually the status quo, which disregards the cost and the effect of market threats arising from the unrealized investment. As a way to compensate high risk, analysts often set the cost of capital too high - higher than it would actually be necessary. This problem can also be approached from the aspect of the inherent difficulty of determining an IT project's capital costs due to the embedded high level of uncertainty.

We can conclude that in practice traditional DCF-based techniques, such as net present value (NPV) calculation, often underestimate the value of complex information technology investments. The underestimation of cash flows and the overestimation of capital costs both cause a bias in the negative direction, thus the above errors may lead to the rejection of viable investments. Although some of the problems listed above stem from the superficiality of the practical application of DCF and the imperfections of parameter estimation, the oversight of decision flexibility and the overrating of risks point to a conceptual issue. This phenomenon has redirected researchers' attention to other valuation methods, like the real option approach.

\section{Real Options in IT Investments}

The criticisms and practical challenges listed above in relation to the DCF method can actually be traced back to two main factors: high uncertainty linked to IT projects and the oversight of management's future decision-making flexibility. Disregard for future flexibility is a conceptual issue in the case of the DCF method, and thus a new valuation approach could be appropriate here. Moreover, the two problems are partially inter-related: the greater the uncertainty, the less it is possible to forecast future cash flows and the more valuable future decision options and flexibility can be. Since the 1990s, reacting on the shortfalls of discounted cash flow-based (DCF) techniques, real-option methods have increasingly gained ground in the international research arena. Following early IT-option studies (e.g. [24]; [30]) this originally financial theory can now be regarded as part of mainstream IT research.

"An option provides its owner the right (but not the obligation) to sell or buy an underlying asset (at or before the expiration date), at a fixed price (called a strike price)." [18, p. 467]. As opposed to the option theory 
originated from the stock exchange, the subject of real options is some kind of tangible asset. The options themselves are not traded but often emerge as exploitable potentials in the company's operation. The following listing presents a synthesis of the most frequently mentioned option types related to IT investments [40], [7]:

- There is in general delay option, i.e. the project launch can be deferred to a later time when we have more information about the given technology (learning option) or when the necessary equipment is available at a more favorable price (timing option).

- In case of an unfavorable turn of events the project can be abandoned in order to avoid further losses. Leasing the technology assets or outsource the given IT functions may inherently establish this kind of abandonment options.

- The scope/scale of the project can be narrowed or broadened any time later whenever it seems favorable (scale option). A special case of this is the possibility of piloting or staggered investment (stage option).

- The given investment can create a basis or an opportunity for further value-creating investments (interproject or growth option).

The above-listed IT options are similar to stock exchange options in three characteristics: they are mostly irreversible; they can be flexibly timed; and the value of the asset is surrounded by great uncertainty [23]. Based on these, many have undertaken to apply valuation methods worked out for capital market options in the case of IT options. For example, Benaroch and Kauffman [8] used a modified version of the Black-Scholes [9] formula in the case of an electronic banking investment, while Taudes, Feurstein and Mild [56] relied on the same method to deal with the valuation problem of a SAP R/2 to $\mathrm{R} / 3$ switch option. The general binomial model of CoxRoss-Rubenstein [19], which is also regarded as a classical financial method, has also been used in the field of IT valuation (e.g. [25]), while Benaroch and Kauffman [8] experimented with the concurrent use of the two models.

There are also examples of the integration of the option view into practical IT decision-making in the corporate sector. According to an American [5] study covering 119 IT managers, $6 \%$ of companies use real-option techniques to analyze IT investment opportunities For example, besides using the DCF technique to quantify the potential value of their investments, HP now also uses real-option valuation (namely the Black-Scholes formula), especially in valuing initial project steps [29, p. 58]. It seems therefore that the concurrent use of the DCF and ROA methodologies can effectively support decisions if geared to the specificities of IT projects as they can mutually offset each other's weaknesses, i.e. DCF's inflexibility and lack of strategic focus and ROA's complexity and heavyhanded communicability [58], [25].

On the other hand, managers often complain about the mathematical complexity or unrealistic assumptions of option pricing formulas (e.g. [5]) or the weaknesses of the method's communicability. That said, the real-option approach to IT investments may not be "doomed to death" after all, as de Jong, Ribbers and van der Zee [37] write in their article entitled "Option pricing for IT valuation: a dead end". All it takes is to shift the emphasis from the precision of calculations to the management approach (Zhu in [54]). While experts prepare the option valuation of an investment opportunity, they assess the sources of project risks and potential future decision points, which in itself is indispensable for effective project management. The fact, that the real-option approach is part of the mainstream research in the field of IT risk management (see e.g. [7]) supports this reasoning too. Also the management's targeted search for and raising awareness of investment options is the first step towards capitalizing on these opportunities. Using the real-option view as a management approach rather than a financial valuation methodology fits into the literature of the option-based approach to strategic investments (e.g. [51]).

\section{III.CONCLUSION}

The real-option view, which is considered to be mainstream, only dominates theory and remains unmanageable for corporate practice. The latter is left to rely on the traditional DCF-based model, advisably placing emphasis on uncovering and estimating all related cash flow streams battling with challenges of uncertainty and intangibility.

In the end the main conclusions of normative IT business value research for management are the following:

1. As corporate budgets tend get tighter and complex ICT systems are still expensive with a comparatively low success rate, it becomes more and more necessary to try to quantify IT business value.

2. When we evaluate an IT project in monetary terms decision support has to try to explore all of the possible value effect - costs and benefits alike. The different theoretic views on this - from transaction cost theory trough total cost of ownership or intangible valuation - will support analysts to be more holistic and comprehensive.

3. For supporting the IT investment decision the valuation has to come up with an aggregate number. While choosing the methodology there will be a trade-off between theoretic rigor and the ease of communicating the results. But whatever our methodological choice is, we have to account for uncertainty, risk and future decision flexibility.

4. Even if the final result of our valuations may still include a lot of uncertainty or unquantifiable future options, it will enable us to identify the most important value sources and success factors and thus implementation and risk management can focus on these factors. This is a merit by itself. The principal function of ex ante IT valuations lies not so much in determining an exact value as in identifying the key factors of value creation.

\section{REFERENCES}

[1] Alchian, A. - Demsetz, H.: „Production, information costs, and economic organization" American Economic Review" 1972. Vol. 62. No. 5. pp 777-795. 
[2] Alter, A. E.: „July 2006 survey: What's the value of IT? At many companies, it's just guesswork" CIOInsight. July 25, 2006. http://www.cioinsight.com/article2/0,1540,1987873,00.asp (10.09.2006)

[3] Anandarajan, A. - Wen, H. J.: „Evaluation of information technology investment" Management Decision. 1999. Vol. 37. No. 4. pp 329-337.

[4] Aranyossy, M. - Nemeslaki, A.: „Információtechnológiai beruházások megtérülésének modellezése: Problémák és megoldások egy vállalati portál példáján” (,IT Investment ROI Modeling: Problems and Solutions for the Case of Enterprise Portals") Budapest Management Review. 2005.Vol. 36. No. 9. pp 24-36.

[5] Arnold, T. - Crack, T. F.: „Using the WACC to value real options” Financial Analysts Journal. 2004. Vol. 60. No. 6. pp 78-82

[6] Banker, R.D. - Kauffman, R.J.:,,Quantifying the business value of information technology: an illustration of the 'business value linkage' framework" 1991. New York University Working Paper Series. Stern School of Business

[7] Benaroch, M. - Lichtenstein, Y. - Robinson, K.: „Real options in information technology risk management: An empirical validation of risk-option relationship" MIS Quarterly. 2006.Vol. 30. No. 4. pp 827-864.

[8] Benaroch, M. - Kauffman, R. J.: „A case for using real options pricing analysis to evaluate information technology investment" Information System Research. 1999. Vol. 10. No. 1. pp70-86.

[9] Black, F. - Scholes, M.: „The Pricing of Options and Corporate Liabilities", Journal of Political Economy. 1973. Vol. 81, pp637654.

[10] Bőgel, Gy.: „Informatikai beruházások üzleti értékelése” (Business valuation of IT investments") CEO. 2003. Vol. 4. No. 3. Melléklet pp 1-12.

[11] Bőgel, Gy.: „Üzleti elvárások - Informatikai megoldások” („Business Expectations - IT Solutions”) 2009. HVG Kiadó. Budapest

[12] Brandenburger, A. M. - Stuart, H. W.: „Value-Based Business Strategy" Journal of Economics and Management Strategy. 1996. Vol. 15. No. 1. pp 5-24.

[13] Cappuccio, D. - Keyworth, B. - Kirwin, W.: „Total cost of ownership: The impact of system management tools" 1996. Technical Report. Gartner Group.

[14] Carr, N. G.: „IT Doesn’t Matter” Harvard Business Review. May 2003, pp 41-49.

[15] Changchit, C. - Joshi, K.D. - Lederer, A.L.: „Process and reality in information systems benefit analysis" Information Systems Journal. 1998. Vol. 8. Issue 2. pp145-162.

[16] Clemons, E. K. - Row, M. C.: „Sustaining IT Advantage: The Role of Structural Differences" MIS Quarterly. 1991. Vol. 15. No. 3. pp 275-292.

[17] Clemons, E. K. - Weber, B. W.: „Strategic information technology investments: Guidelines for decision making" Journal of Management Information Systems. 1990. Vol. 7. No.2. pp 9-28.

[18] Copeland, T. - Koller, T. - Murrin, J.: „Vállalatértékelés” („Valuation”) 1999. Panem - John Wiley \& Sons. Budapest

[19] Cox - Ross - Rubinstein: „Option Pricing: A Simplified Approach” Journal of Financial Economics. 1979. No. 7. pp 229-263.

[20] Cronk, M. C., \& Fitzgerald, E. P.. Understanding "IS business value": derivation of dimensions. Logistics Information Management. 1999. Vol. 12. No. 1/2. pp 40-49.

[21] Damodaran, A.: „Dealing with intangibles: Valuing brand names, flexibility and patents" 2006. http://pages.stern.nyu.edu/ adamodar/ (2006.05.03)

[22] Deloitte: „Valuing intangible assets. What are they really worth?” January 2006

[23] Dewan, S. - Shi, C. - Gurbaxani, V. : „Investigating the risk-return relationship of information technology investment: Firm-level empirical analysis" Graduate School of Management. University of California. Irvine. Working paper. July, 2003

[24] Dos Santos, B.L.: „Justifying Investment in New Information Technologies" Journal of Management Information Systems. 1991. Vol. 7. No. 4. pp 71-89.

[25] Ekström, M. A. - Björnsson, H. C.: „Evaluating IT investments in construction. Accounting for strategic flexibility" 2003. Stanford University. Center for Integrated Facility Engineering. Technical Report No. 136
[26] Ellison, R. J.- Moore, A. P.: „Trustworthy Refinement Through Intrusion-Aware Design (TRIAD)" 2003. Carnegie Mellon University, Software Engineering Institute. Technical Report CMU/SEI-2003-TR-002

[27] Ellram, L. M.: „Total Cost of Ownership: Elements and Implementation" International Journal of Purchasing and Material Management. 1993. Vol. 29. No. 4. pp 3-10.

[28] Gartner: Gartner Says Worldwide IT Spending on Pace to Grow 2.1

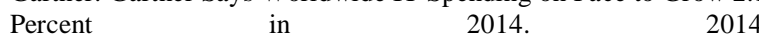
http://www.gartner.com/newsroom/id/2783517 (11.07.2014.)

[29] Green, C. - Maranhao, C.: „Beyond budget” PM Network. September 2006. www.pmi.org. (08.12.2006) pp 56-60.

[30] Grenadier, S. - Weiss, A.: „Optimal migration strategies for firms facing technological innovations: An option pricing approach" 1997. Working Paper. Stanford Business School

[31] Gurbaxani, V. - Whang, S.: „The impact of information systems on organisations and markets" Communications of the ACM. 1991. Vol. 34. No. 1. pp 59-73.

[32] Hares, J. - Royle, D.: „Measuring the Value of Information Technology" 1994. Wiley. Chichester

[33] Hitt, L. M.: „Information technology a nd firm boundaries: Evidence from panel data" Information Systems Research. 1999. Vol. 10. No. 2. pp 134-149.

[34] Hitt, L. M. - Brynjolfsson, E.: „The three faces of IT value: theory and evidence" Proceedings of 15th International Conference on Information Systems. December, 1994. pp 263-277.

[35] Hitt, L. M. - Frei, F. X. - Harker, P. T.: „How Financial Firms Decide on Technology" 1999. Working Paper. The Warton School. University of Pennsylvania

[36] Hull, J.C.: „Options, Futures, and Other Derivatives” 2003. Fifth Edition. Prentice-Hall. New Jersey

[37] de Jong, B. - Ribbers, P. M. A. - van der Zee, H. T. M.: „Option pricing for IT valuation: a dead end" Electronic Journal of Information Systems Evaluation. 1999. Vol. 2. No. 1. http://www.ejise.com/volume-2/volume2-issue1/issue1-art1.htm

[38] Juhász, P.: A mérlegen kívüli tételek a magyar vállalatok müködésében („Off-Baance Sheet Items in Hungarian Firms”) Hitelintézeti Szemle. 2012. Vol. 11. No.1. pp 24-46.

[39] Jordan, E.: „A global strategy for building information assets: an agenda for information professionals" Proceedings of ACIS 1995. Perth. 26-29. September. pp 915-26.

[40] Kumar, R. L.: „Managing risks in IT projects: an option perspective" Information \& Management. No. 40. 2002. pp 63-74.

[41] Kumar, K. - Van Dissel, H. G. - Bielli, P.: „The Merchant of PratoRevisited: Toward a Third Rationality of Information Systems" MIS Quarterly. 2002. Vol. 22. No. 2. pp 199-226.

[42] Lech, P.: "Proposal of a Compact IT Value Assessment Method" The Electronic Journal Information Systems Evaluation 2007. Vol. 10. No. 1. pp $73-82$. available online at www.ejise.com

[43] Melville, N. - Kraemer, K. - Gurbaxani, V.: „Review: Information technology and organizational performance: An integratice model of IT business value" MIS Quarterly. 2004. Vol. 28. No. 2. pp 283322.

[44] Murphy, K. E. - Simon, S. J.: „Intangible benefits valuation in ERP projects" Information Systems Journal. 2002. Vol. 12. No. 4. pp 301-320.

[45] Nemeslaki, A. - Aranyossy, M.: „Az információtechnológia vállalati értékteremtésének elméletei, szemléletmódjai és módszerei” (,Theories, Views and Methodologies of IT Business Value") Budapest Management Review. 2005. Vol. 36. No. 7-8. pp 27-38.

[46] Piccoli, G. - Ives, B.: „Review: IT-Dependent Strategic Initiatives and Sustainable Competitive Advantage: A Review and Synthesis of the Literature" MIS Quarterly. 2005. Vol. 29. No. 4. pp 747775 .

[47] Reilly, R. F.: The valuation of proprietary technology. Management Accounting. 1998. Vol. 79. pp 45-49.

[48] Remenyi, D. - Money, A. - Twite, A.: „A Guide to Measuring and Managing IT Benefits" 1993. NCC Blackwell. Manchester.

[49] Silvius A.J.G. "Does ROI Matter? Insights into the true Business Value of IT" The Electronic Journal Information Systems Evaluation. 2006. Vol. 9. No. 2. pp 93 - 104. available online at www.ejise.com

[50] Smith, D.J. - Schuff, D. - St. Louis, R.: „Managing your total IT cost of ownership" Communications of the ACM. 2002. Vol. 45. No. 1. pp 101-106 
[51] Smit, H. T. J. - Trigeorgis, L.: „Strategic Investment: Real Options and Games", 2012. Princeton University Press

[52] Strassmann, P.A.: „The Business Value of Computers” 1990. The Information Economics Press. New Canaan

[53] Szatmári, F.: „Közgazdasági értékteremtés vizsgálata a hazai vállalkozások infokommunikációs beruházásainál” („Economic value creation of Hungarian firms IT investments") 2011. PhD dissertation. University of Kaposvár, Hungary

[54] Tallon, P. P. - Kauffman, R. J. - Lucas, H. C. - Whinston, A. B. Zhu, K.: „Using real option analysis for evaluating uncertain investments in information technology: Insights from the ICIS 2001 debate" Communications of the Association for Information Systems, 2002. Vol. 9. pp136-167.

[55] Tambe, P. - Hitt, L. - Brynjolfsson, E.: „The Price and Quantity of IT-Related Intangible Capital" Proceedings of the Thirty Second International Conference on Information Systems, Shanghai 2011. Economics and Value of IS

[56] Taudes, A. - Feurstein, M. - Mild, A.: „Options Analysis of Software Platform Decisions: A Case Study" MIS Quarterly. 2000. Vol. 24. No. 2. pp 227-243.

[57] Upton, W. S. Jr.: „Business and financial reporting. Challenges from the New Economy" Financial Accounting Series. 2001. No. 219 - A Financial Accounting Standards Board of the Financial Accounting Foundation

[58] van Putten, A. B. - MacMillan, I. C. (2004): „Making real options really work" Harvard Business Review. December 2004. pp 134141.

[59] Virág, M. - Fiáth, A.: Financial Ratio Analysis. 2010. AULA Kiadó. Budapest.

[60] Watjatrakul, B.: „Determinants of IS sourcing decisions: A comparative study of transaction cost theory versus the resourcebased view" The Journal of Strategic Information Systems. 2005. Vol. 14. No. 4. pp 389-415.

[61] Williamson, O. E.: „The economics of organization: The transaction cost approach" American Journal of Sociology. 1981. Vol. 87. No. 3. pp 548.

\section{BIOGRAPHY}

Marta Aranyossy, $\mathrm{PhD}$ works as an assistant professor at the Department of Enterprise Finances, Corvinus University of Budapest, Hungary. Her current focus of research includes IT business value, e-government value, IT project success and failure as well as valuation of ecommerce and technology firms. 